\title{
Fiscal Year 1992 Report on Archaeological Surveys of the 100 Areas, Hanford Site, Washington
}

\author{
M. K. Wright
}

September 1993

Prepared for

the U.S. Department of Energy

under Contract DE-AC06-76RLO 1830

Pacific Northwest Laboratory

Richland, Washington 99352 


\section{DISCLAIMER}

This report was prepared as an account of work sponsored by an agency of the United States Government. Neither the United States Government nor any agency thereof, nor any of their employees, make any warranty, express or implied, or assumes any legal liability or responsibility for the accuracy, completeness, or usefulness of any information, apparatus, product, or process disclosed, or represents that its use would not infringe privately owned rights. Reference herein to any specific commercial product, process, or service by trade name, trademark, manufacturer, or otherwise does not necessarily constitute or imply its endorsement, recommendation, or favoring by the United States Government or any agency thereof. The views and opinions of authors expressed herein do not necessarily state or reflect those of the United States Government or any agency thereof. 


\section{DISCLAIMER}

Portions of this document may be illegible in electronic image products. Images are produced from the best available original document. 


\section{Executive Summary}

During FY 1992, the Hanford Cultural Resources Laboratory (HCRL) conducted a field survey of the 100-HR-3 Operable Unit (600 Area) and tested three sites near the 100 Area reactor compounds on the U.S. Department of Energy's Hanford Site at the request of Westinghouse Hanford Company. These efforts were conducted in compliance with Section 106 of the National Historic Preservation Act (NHPA) and are part of a cultural resources review of 100 Area Comprehensive Environmental Response, Compensation, and Liability Act (CERCLA) operable units in support of CERCLA characterization studies.

The results of the FY 1992 survey and test excavation efforts are discussed in this report. HCRL surveyed 518 ha in the 100-HR-3 Operable Unit and conducted test excavations at three prehistoric sites near the $100-\mathrm{F}$ and $100-\mathrm{K}$ reactors to determine their eligibility for listing on the National Register of Historic Places. 


\section{Acknowledgments}

The discussion of test excavations and methods employed at sites 45BN432, 45BN433, and 45BN423 was authored by H. A. Gard, and his efforts are gratefully acknowledged. 
. 


\section{Contents}

Executive Summary $\ldots \ldots \ldots \ldots \ldots \ldots \ldots \ldots \ldots \ldots \ldots \ldots$ iii

Acknowledgments $\ldots \ldots \ldots \ldots \ldots \ldots \ldots \ldots \ldots \ldots \ldots \ldots \ldots \ldots$

Introduction $\ldots \ldots \ldots \ldots \ldots \ldots \ldots \ldots \ldots \ldots \ldots \ldots \ldots \ldots \ldots \ldots \ldots \ldots$

Project Area Description $\ldots \ldots \ldots \ldots \ldots \ldots \ldots \ldots \ldots \ldots \ldots \ldots$

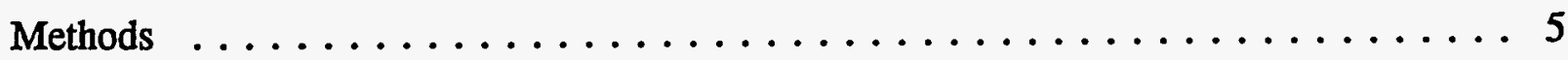

Previous Archaeological Studies $\ldots \ldots \ldots \ldots \ldots \ldots \ldots \ldots \ldots \ldots$

Historic Native American Use of the Project Area . . . . . . . . . . . 9

Cultural Resources Sites Recorded $\ldots \ldots \ldots \ldots \ldots \ldots \ldots \ldots \ldots \ldots$

100 Area Test Excavations at Sites 45BN432, 45BN433, and 45BN423 $\ldots \ldots \ldots 21$

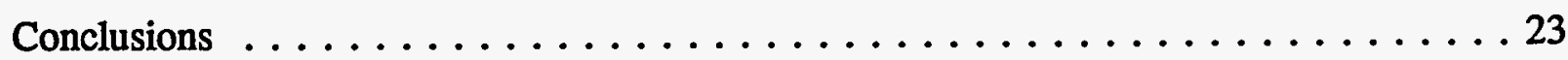

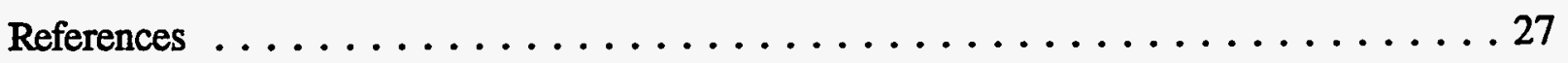




\section{Figures}

1 The Hanford Site with 100 Area Reactor Compounds $\ldots \ldots \ldots \ldots \ldots$

2 Map of the 100-HR-3 Operable Unit and the 100-HR-1, 100-HR-2, 100-DR-1, 100-DR-2, 100-DR-3, and 100-IU-4 Operable Units . . . . . . . 7

3 Plot Division and Area Surveyed in the 100-HR-3 Operable Unit . . . . . . . . . 12

\section{Tables}

1 Archaeological Sites Discovered During the FY 1992 Archaeological Survey of the Hanford Site 100-HR-3 Area . . . . . . . . . . . . 13

2 FY 1992 Sites at Risk from Characterization Work . . . . . . . . . 24 


\section{Introduction}

The U.S. Department of Energy is conducting characterization studies of numerous Comprehensive Environmental Response, Compensation, and Liability Act (CERCLA) operable units on the Hanford Site in southeastern Washington State. Among these are the 100Area reactor compounds and their vicinities, including the 100-B/C, 100-D, 100-F, 100-H, 100-K; and 100-N Areas. Characterization studies, which entail excavation of many groundwater wells and surface geophysical and radiological surveys, may potentially impact significant cultural properties, as might the cleanup activities that will follow. Therefore, Section 106 of the National Historic Preservation Act (NHPA) (16 USC 470 et seq.), which specifies that federal land managers must take into consideration the impact of any undertaking on significant historic properties, applies. Historic properties are archaeological, historic, or cultural sites that meet criteria for nomination to the National Register of Historic Places. If no inventory of historic properties has been conducted in the area of potential effect, such an inventory must be conducted before the undertaking begins.

In April 1990, Westinghouse Hanford Company (WHC) funded the Hanford Cultural Resources Laboratory (HCRL) to initiate the Section 106 review of six 100 Area operable units. That work included 1) a literature search to determine if previous archaeological surveys had been conducted in the vicinity of any of the operable units and, if so, what sites had been located; 2) an archaeological survey of any areas not previously inspected; and 3) interviews with knowledgeable members of local Native American tribes and bands to identify culturally important localities.

During the FY 1991 field season, HCRL staff conducted a literature review and survey of the 100 Area reactor compounds and those portions of the Columbia River shoreline adjacent to the compounds. The reactor compounds, 100-B/C, 100-D, 100-F, 100-H, 100-K, and $100-\mathrm{N}$ include a total of $1834 \mathrm{ha}$, of which 770 ha were surveyed. Twenty-five sites and one isolated find were recorded in FY 1991 (Chatters et al. 1992); six previously recorded sites exist in the immediate area. A majority of these sites (24) represent Native American occupation, and the remainder (6) are associated with Euro-American settlement.

During the FY 1992 field season, 518 ha were surveyed in the 100-HR-3 Operable Unit outside of the reactor compounds. Thirty-eight sites and one isolated find were recorded in the Operable Unit. Most sites (27) represent Euro-American settlement activities, five represent Native American occupation, three are associated with military activities, and three sites contain both historic and prehistoric components. In addition to the 100-HR-3 survey efforts, three sites, 45BN423, 45BN432, and 45BN433, were tested to determine eligibility for inclusion on the National Register of Historic Places. 


\section{Project Area Description}

The project area for FY 1992 included three areas: 1) the portion of the Hanford Site designated as the 100-HR-3 Operable Unit, which includes lands outside the 100-DR-1, 100-DR-2, 100-DR-3, 100-IU-4, 100-HR-1, and 100-HR-2 operable units, 2) archaeological test excavations at sites 45BN432 and 45BN433 near the 100-F Reactor, and 3) archaeological test excavations at site 45BN423 near the 100-K Reactor (Figure 1). Approximately $23 \mathrm{~km}^{2}$ $\left(9 \mathrm{mi}^{2}\right)$ are included in the 100-HR-3 Operable Unit. The 100-HR-3 Operable Unit is located in the Pasco Basin near the northern extent of the Hanford Site in southeastern Washington State. It is bounded to the north, east, and west by the Columbia River and on the south by a transverse line that extends east and west from shoreline to shoreline just south of the lower extent of the 100-DR-3 Operable Unit boundary. The landform is generally flat, with an elevation range from $116 \mathrm{~m}$ (380 ft) near the river to approximately $140 \mathrm{~m}(460 \mathrm{ft})$ inland. A steep cobble beach of up to $9 \mathrm{~m}(30 \mathrm{ft}$ ) drops in grade along the eastern and northern shoreline to a nearly flat cobble beach along the western shoreline. The sandy floodplain terraces were deposited during the Holocene (last 10,000 years). Inland areas are broad flats broken only by stabilized dunes. The area from west of the 100-N Area to the western edge of the 100-D Area differs from this general pattern. In this portion of the 100-HR-3 Operable Unit, naturally occurring large, rounded gravel mounds are common. At the 100-F Reactor the landforms appear to be early Holocene floodplains that contain undated bedded fine sand and silt deposits. In the 100-K Area, both Pleistocene and Holocene terraces are present (Chatters et al. 1992).

In each of the three areas, vegetation is dominated by cheatgrass (Bromus tectorum), resulting from several decades of land-use activities associated with livestock grazing, crop irrigation, and orchard production. Also present are big sagebrush (Artemisia tridentata), tumble mustard (Sysimbrium spp.), Russian thistle (Salsola kali), rabbit brush (Chrysothamnus spp.), and needle-and-thread grass (Stipa comata). Riparian habitats along the Columbia River contain a variety of scattered deciduous shrubs and trees including shrub willow (Salix exigua and others), mulberry trees (Morus alba) and black locust (Robinia pseudo-acacia).

Wildlife in the project area includes migrant waterfowl, Great Basin Canada geese (Branta canadensis moffitti), mule deer (Odocoileus hemionus), coyote (Canis latrans), and badger (Taxidea taxus). 


\section{$\nabla$}

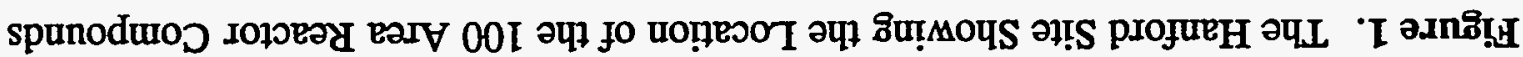

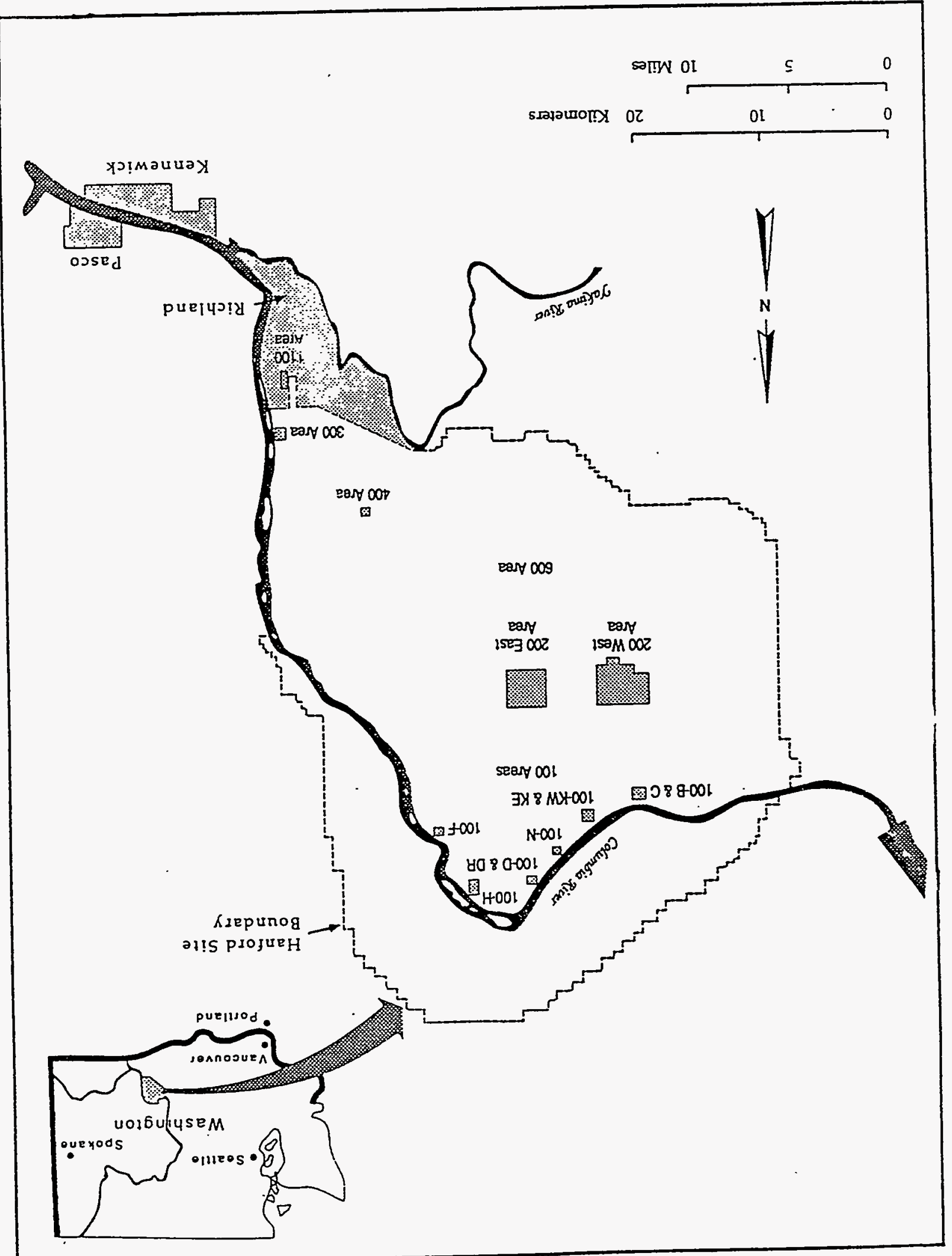




\section{Methods}

This study consists of a literature and records review, surface survey, and test excavations. The procedures used in this endeavor follow specifications in the Hanford Cultural Resources Management Plan, Section 3.1.1. (Chatters 1989, pp. 3.2-3.12), and the Hanford Cultural Resources Laboratory Procedures Handbook (Dawson 1993).

The literature review during February 1992 entailed a search of the HCRL's site survey files, archaeological site records, and survey reports documenting early survey efforts on the Hanford Site (Rice 1968a, 1968b, 1983). These records contain maps of previously surveyed areas and all recorded archaeological and historic sites.

The archaeological survey began with the inspection of historical aerial photographs (1941) to identify areas that contained evidence of land-use activities; these areas were then intensively surveyed. .Of the total 1058 ha to be surveyed in the 100-HR-3 Operable Unit, approximately 518 ha were intensively surveyed in FY 1992. The intensive survey methodology deviates from the "random survey" approach originally planned. The decision to complete a random survey in the 100-HR-3 Operable Unit was based on the understanding that all improvements by Euro-American landowners had been demolished and that little, if any, evidence of early farmstead activities remained. During initial survey efforts in June 1992, HCRL staff encountered many historic dumps, historic artifacts, and building foundations. Because of the high density of historic sites encountered, it was determined that a random survey approach would not effectively provide the database required to manage cultural resources in the 100 Area (i.e., a random survey would not afford HCRL staff the opportunity to record all of the sites present in the operable units). Without a complete cultural resource database, HCRL staff would be unable to respond to future remediation projects without returning to the 100 Area to complete the additional survey and documentation necessary for making informed management decisions. Using the intensive survey approach, approximately one-half of the 100 Area was surveyed during FY 1992.

Intensive survey methods required that staff members search the land surface and record all observations in parallel transects spaced a maximum of $20 \mathrm{~m}$ apart. Site forms were completed for each isolated artifact or site discovered, and sites were described, sketch-mapped, and photographed. Artifacts important to site interpretation were photographed, and diagnostic or unique artifacts were collected. Archaeological site forms that were completed during the 1992 field season are included with this report for submittal to the Washington State Historic Preservation Office (SHPO) in Olympia, Washington. The SHPO maintains a complete file of prehistoric and historic archaeological sites for the state of Washington. 
Three archaeological sites, 45BN432, 45BN433, and 45BN423 were tested to determine site significance and eligibility for inclusion on the National Register of Historic Places.

For two archaeological sites tested near the 100-F reactor, 45BN432 and 45BN433, the excavation strategy consisted of imposing a standard Cartesian coordinate grid system across the study area to provide horizontal controls. This allowed accurate placement of $3510-\mathrm{cm}$ diameter auger sample holes spaced at $10-\mathrm{m}$ intervals across the area. Auger tests were excavated in 10-cm increments, with all soils sieved through 4-mm mesh shaker screens to ascertain the presence, type, and depth of cultural material. The results of the auger test data were then plotted both horizontally and vertically to create a three-dimensional map of the distribution of archaeological deposits and their correlations to soil types. Several cultural zones, or strata, ranging in depths from $20 \mathrm{~cm}$ to $160 \mathrm{~cm}$ below ground surface, were identified. Auger tests yielded fine eolian sands overlying bedded fluvial sediments that overlie a river cobble substrate. Several pockets of redeposited Mazama ash $(6,850$ B.P. $\neq 40)$ were also found (Bacon 1983). Using the auger tests as a guide, three $1 \mathrm{~m} \mathrm{x} 1 \mathrm{~m}$, one $1 \mathrm{~m} \mathrm{x} 2 \mathrm{~m}$, and one $2 \mathrm{~m} \times 2 \mathrm{~m}$ excavation units were placed across the site to sample the areas of densest cultural deposits and to collect stratigraphic information on the depositional history of the sites. All test units, with the exception of the $2 \mathrm{~m} \times 2 \mathrm{~m}$ unit, were excavated by hand in 10-cm arbitrary levels, and all soils were passed through 4-mm mesh shaker screens. The $2 \mathrm{~m} \mathrm{x} 2 \mathrm{~m}$ unit was excavated partly by backhoe due to sidewall instability. Test unit depth ranged from $80 \mathrm{~cm}$ to $160 \mathrm{~cm}$ below ground surface.

At Site 45BN423, near the $100-\mathrm{K}$ reactor, the excavation strategy was the same as that employed at sites $45 \mathrm{BN} 432$ and 45BN433. Twenty-eight auger tests indicated several buried cultural strata ranging from $20 \mathrm{~cm}$ to over $2 \mathrm{~m}$ below ground surface. Because of the depth of these deposits, three $1 \mathrm{~m} \mathrm{x} 2 \mathrm{~m}$ excavation units were placed across the site. Depths excavated ranged from $160 \mathrm{~cm}$ to $200 \mathrm{~cm}$ below ground surface.

Lithic analysis of recovered cultural debitage from sites 45BN432, 45BN433, and 45BN423 included descriptions of the flake type, material, completeness of specimen, reduction type, platform, length, width, thickness, and weight of each item. Analysis of faunal remains is not yet completed. 


\section{Previous Archaeological Studies}

Before 1991, surveys had not been conducted in most parts of the 100 Area Operable Unit although extensive surveys had been conducted up to area boundaries.

In 1991, HCRL staff surveyed inside the perimeter fences of 100-B/C, 100-D, 100-F, and $100-\mathrm{H}$ reactors (Figure 2). Shoreline surveys were also conducted north of $100-\mathrm{K}$ Reactor, 100-F Reactor, 100-D Reactor, and 100-B/C Area Reactors (Chatters et al. 1992). Twentyfive archaeological sites and one isolated find were found in and near the reactor compounds; six were historic Euro-American sites, one was an ethnographic Wanapum fishing village, and 18 were prehistoric sites (Chatters et al. 1992).

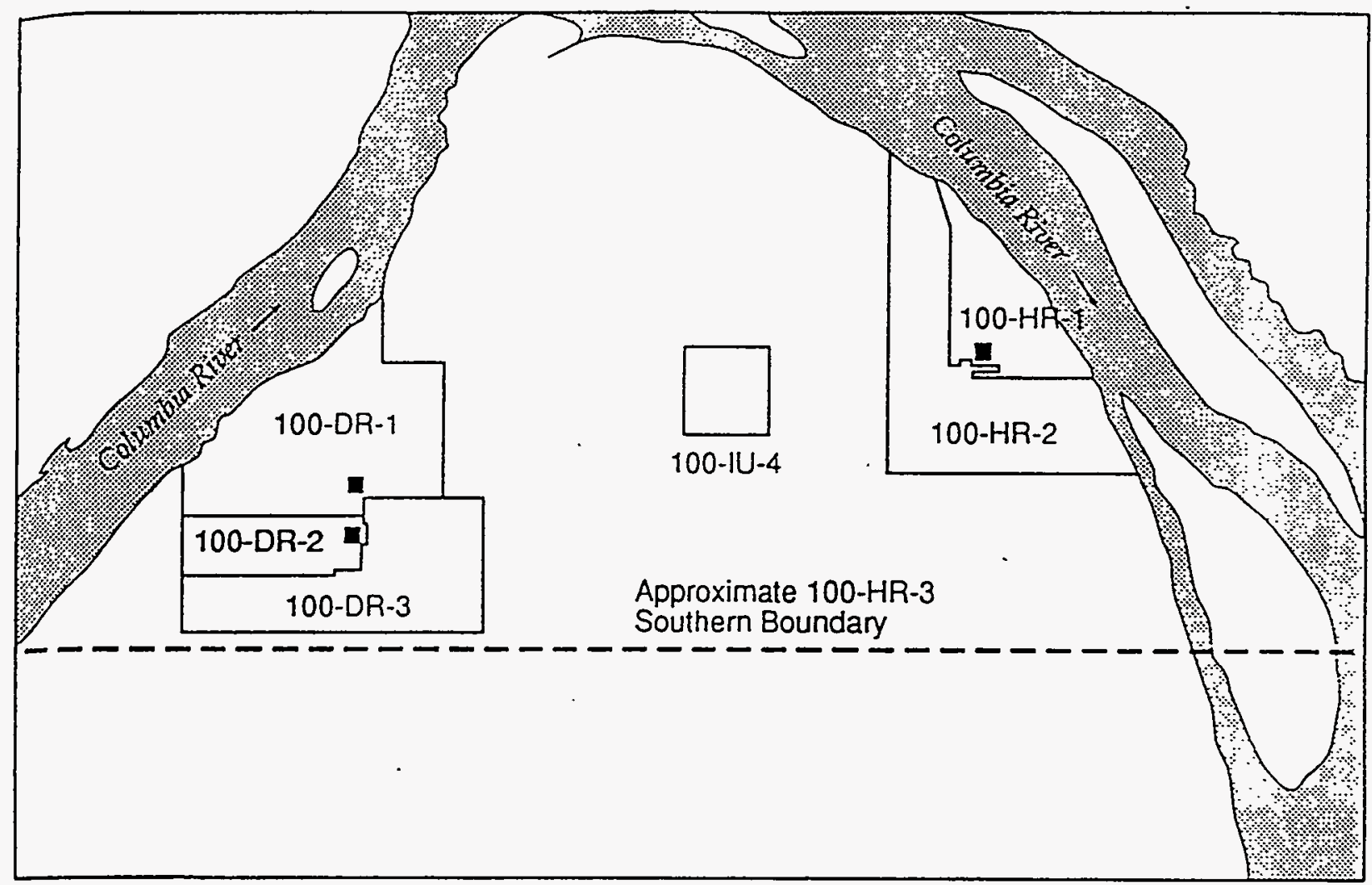

Figure 2. Map Showing the Location of the 100-HR-3 Operable Unit and the 100-HR-1, 100-HR-2, 100 DR-1, 100-DR-2, 100-DR-3, and 100-IU-4 Operable Units 
Earlier surveys were conducted by Rice (1968b) and the mid-Columbia Archaeological Society. The Society, directed by Rice, completed a survey of the proposed Ben Franklin Dam reservoir pool, which included all lands below an elevation of $122 \mathrm{~m}(400 \mathrm{ft})$. Numerous sites were identified, including sites 45BN149, 45BN150, and 45BN151 between the 100-K and 100-N Areas. These sites, two campsites, and a cemetery have been placed on the National Register of Historic Places as the Ryegrass Archaeological District. The area of the Hanford Generating Plant was also surveyed (Rice 1983) as part of investigations for the Washington Public Power Supply System in the late 1970s and early 1980s. During these surveys, Rice (1983) identified and conducted test excavations at two archaeological sites, $45 \mathrm{BN} 179$ and 45BN180, both of which are contiguous with site 45BN149 and can be considered part of it. Site 45BN179 is a stratified campsite that was first occupied around 7000 years ago and finally used by the historic Wanapum Tribe within the past century-and-ahalf. Site $45 B N 180$ is a pair of small, late prehistoric house pits. Of the two, Rice considered site 45BN179 to be eligible for the National Register of Historic Places. Because the sites are legitimately considered as part of an existing historic property, we will treat them as such. Altogether there are five previously recorded archaeological sites within the project area, all of which are included in the Ryegrass Archaeological District listing on the National Register of Historic Places (Chatters et al. 1992). 


\section{Historic Native American Use of the Project Area}

It is customary in archaeological survey reports to include a description of Native American use of the project area. This information is typically obtained from such references as Relander's Drummers and Dreamers (1956), which identifies numerous sites in the vicinity of the 100 Areas including Coyote Rapids, the berg mounds of the 100-N and 100-D Areas, and the Columbia River shoreline opposite White Bluffs. In this report, we will defer the discussion of Native American use and culturally important areas until the tribes themselves have been consulted (Chatters et al. 1992). Consultation is expected to occur during the latter portion of FY 1993. 


\section{Cultural Resources Sites Recorded}

Thirty-nine cultural resource sites were encountered in the 100-HR-3 Operable Unit during the 1992 field season. This large area was divided into 17 survey plots for ease in documentation and reporting (Figure 3). The surveyed portions and the sites found there are described in this section (Table 1).

HI-92-006. An isolated clear three-sided glass bottle with the trademark "Norwich" was noted at this site. The bottle was not collected.

HT-92-011. Over 200 artifacts were scattered in a $200 \mathrm{~m}^{2}$ area at the corner of an old field. Domestic artifacts included but were not limited to, hole-in-top cans manufactured from 1935 to 1945 or from 1950 to 1987 , white ceramics, Depression-era glass fragments, clear glass canning jars, and amethyst glass fragments. Also present were smudge pots, old truck suspension parts, rolls of wire, a hatchet, and a well-used ax/maul head. The dump is near building foundations at HT-92-021.

HT-92-012. This is a small historic dump likely associated with one of three household complexes located within $0.6 \mathrm{~km}(0.25$ miles $)$ of this location. The debris is near the northeastern comer of a small field and is approximately $100 \mathrm{~m}$ west of HT-92-018. The artifacts represent domestic and machinery-related activities. Oil cans (green) and batteries suggest an army presence. Over 124 artifacts were visible on the surface including sanitary cans, graniteware, crockery fragments, glass fragments, a lard bucket, a galvanized bucket, an oil can, batteries, and a barrel hoop.

HT-92-013. Three trash dumps located in proximity to each other contain both army and domestic artifacts including white ceramics, sanitary cans, amethyst glass, an aluminum sauce pan, paint cans, sardine cans, and army debris. All three locations contain matching ceramic sherds that have been separated, i.e., plate fragments from a single plate were found in one dump and also in another. Historic aerial photography (1941) indicates that a multistructure complex and large orchard were located immediately north of these dump locations.

HT-92-014. Both prehistoric and historic components were found at this site located along the 190-m contour line. Remnants of several features were evident at this location: a concrete pad, coal pile remnants, and a buried concrete tank. Gravel fill and lithic debris were found immediately north of the concrete pad. The discrete location of lithics with the gravel fill suggest that these deposits were brought to the site from another location. The 1941 aerial photograph of this site indicates that several structures, fields, and orchards (both south and

north of the structures) once stood here. A major road and driveway, apparently well-used in 




Figure 3. Plot Division and Area Surveyed in the 100-HR-3 Operable Unit 
Table 1. Archaeological Sites Discovered During the FY 1992

Archaeological Survey of the Hanford Site 100-HR-3 Area .

\begin{tabular}{|c|c|c|c|}
\hline $\begin{array}{l}\text { Temporary } \\
\text { Number }\end{array}$ & Plot Number & $\begin{array}{c}\text { Washington } \\
\text { Number } \\
\end{array}$ & Site Type \\
\hline HI-92-006 & Plot 12 & not assigned & Historic Isolate \\
\hline HT-92-011(1) & Plot 2 & not assigned & Historic Dump \\
\hline HT- $-92-012^{(a)}$ & Plot 2 & not assigned & Historic Dump \\
\hline HT-92-0131(a) & Plot 2 & not assigned & Historic Dump \\
\hline HT-92-014(a) & Plot 4 & not assigned & Historic Complex, Prehistoric Component \\
\hline HT-92-015(a) & Plot 8 & not assigned & Prehistoric Cairn \\
\hline HT-92-016(n) & Plot 5 & not assigned & Historic Complex \\
\hline HT-92-017(a) & Plot 5 & not assigned & Historic Complex \\
\hline HT $-92-018^{(()}$ & Plot 7 & not assigned & Historic Complex \\
\hline HT-92-019(n) & Plot 7 & not assigned & Historic Complex \\
\hline HT-92-020(a) & Plot 1 & not assigned & Historic Complex \\
\hline HT-92-021(a) & Plot 3 & not assigned & Historic Complex \\
\hline HT-92-023(1) & Plot 8 & not assigned & Historic Complex \\
\hline 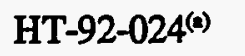 & Plot 4 & not assigned & Historic Complex \\
\hline HT-92-025 & Plot 9 & not assigned & Historic Fieldstone and Dump \\
\hline HT-92-026(n) & Plot 10 & not assigned & Historic Complex \\
\hline HT-92-027(n) & Plot 11 & not assigned & Military Site \\
\hline HT-92-028 & Plot 11 & not assigned & Historic Complex \\
\hline HT-92-029 & Plot 11 & not assigned & Historic Complex \\
\hline HT-92-030 & Plot 11 & not assigned & Historic Complex \\
\hline HT-92-031 & Plot 11 & not assigned & Historic Complex \\
\hline HT-92-032(a) & Plot 11 & not assigned & Historic Complex and Prehistoric Component \\
\hline 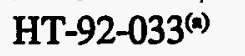 & Plot 12 & not assigned & Prehistoric \\
\hline HT-92-034(^) & Plot 12 & not assigned & Historic Dump and Rock Alignment \\
\hline HT-92-035(合 & Plot 12 & not assigned & Historic Complex \\
\hline HT-92-036(^) & Plot 12 & not assigned & Prehistoric \\
\hline HT-92-037 $7^{(n)}$ & Plot 12 & $45 \mathrm{BN} 145$ & Prehistoric Camp \\
\hline HT-92-038 $8^{(a)}$ & Plot 12 & not assigned & Historic Dump \\
\hline HT-92-039(n) & Plot 12 & not assigned & Historic Dump \\
\hline HT-92-040(n) & Plot 12 & not assigned & Historic Dumps and Rock Piles \\
\hline HT-92-041( & Plot 12 & not assigned & Military Gun Site \\
\hline HT-92-042(n) & Plot 12 & not assigned & Historic Dump \\
\hline HT-92-043(a) & Plot 16 & not assigned & Prehistoric Camp \\
\hline HT-92-044(a) & Plot 16 & not assigned & Historic Dumps \\
\hline HT-92-045 & Plot 7 & not assigned & Army Baseball Field \\
\hline HT-92-046 & Plot 17 & not assigned & Historic Complex and Prehistoric Component \\
\hline HT-92-045 & Plot 17 & not assigned & Historic Complex \\
\hline HT-92-048(a) & Plot $13 \& 14$ & not assigned & Historic Dumps \\
\hline HT-92-049(ฉ) & Plot 3 & not assigned & Historic Dump \\
\hline
\end{tabular}

(a) Sites listed or considered eligible for listing on the National Register of Historic Places. 
1941, were still evident in 1992. The road connected HT-92-014 with a second group of buildings to the west (recorded as HT-92-024 during the 1992 field season).

HT-92-015. This historic site contains a domestic dump, pieces of agricultural machinery, fence segments, and a single structure foundation. It is likely that the complex represents a single farmstead with orchards, dwelling, and associated farm machinery.

HT-92-016. This extensive site contains a variety of historic artifacts, evidence of structure foundations, and an irrigation system. A total of 11 distinct features was recorded. Interestingly, the presence of a rubber tire, rubber horseshoe, and leather harness fragments suggest the use of both mechanical and animal-powered equipment. The 1941 aerial photographs suggest that a significant portion of this farmstead was devoted to both cultivated and uncultivated grass fields, with very little land allotted to orchards. Further, field parameters are defined by natural landform contours and, as a result, fields are diagonal instead of rectangular or square as is common to most of the other farmsteads in the 100 Area.

HT-92-017. This domestic dump scatter and foundation complex is located immediately south of the $122-\mathrm{m}(400 \mathrm{ft})$ contour line and directly east of the extensive artifact and feature complex at HT-92-016. Over 500 artifacts were found scattered throughout the site. Although concrete foundations were not found here, concrete triangular pier blocks located south of the remaining trees match the location of a rectangular structure pictured in the 1941 aerial photograph. This same photograph shows a grouping of at least five large trees in the northeastern corner of the site; not all of these trees are still present but evidence of activity areas and small structures are highly visible. A wood cookstove and other assorted domestic artifacts were found across the road to the east of HT-92-017.

HT-92-018. This historic site contains a dump and at least one structure foundation although leveled flat areas throughout the site suggest that several structures were once present. Of particular interest is a stone wall, $60 \mathrm{~m}$ long, at the southern extent of the $32 \mathrm{ha}$ (80 acres) of this farmstead. The 1941 aerial photograph appears to show two structures and at least six large trees at this location. When recorded during the 1992 field season, only dead trees were present.

HT-92-019. Over 900 artifacts were found on the surface of this extensive historic site. A total of five foundations and two concrete slabs were recorded here. Interestingly, the historic aerial photograph shows that in 1941 very little, if any, effort had been made to establish fields or orchards. The wealth of artifact debris recorded here is in direct conflict with the minimal impacts shown on the aerial photograph, suggesting that this farmstead was established after the aerial photograph date of July 15, 1941 and before the 1943 demolition to make way for Hanford Engineer Works. 
HT-92-020. The 1941 aerial photograph shows at least four, and possibly five structures. The layout of HT-92-020 and the adjacent field/orchard configuration suggests that all-16 ha ( 40 acres) of this block was owned by one family or individual. Nearly half of the 16 ha were devoted to orchard in 1941. When HT-92-020 was recorded in 1992, surveyors recognized five distinct locations retaining either cement foundations or leveled, rectangular areas of soil compaction. In addition, faint roadways, irrigation pipe, and a light, but extensive scatter of artifact debris confirmed that several structures had once stood at this location. The artifacts suggest a variety of past activities and the presence of a home (e.g., white ironstone, glass fragments, a cookstove, building debris, crop irrigation, orchard smudge pots).

HT-92-021. This historic complex includes a semiburied basement or cellar, a second foundation, fence posts, car parts, and a small dump. The potential connection between this site and the large domestic scatter immediately adjacent and west of this complex (HT-92-011) is worthy of investigation because of the apparent lack of domestic debris at HT-92-021. The 1941 aerial photograph shows that with the exception of a few acres, this farmstead of 8 ha (20 acres) was almost entirely devoted to orchard production.

HT-92-023. Over 575 historic artifacts are widely scattered amidst the remains of four features; three foundations and one cleared/compacted area with a trash scatter. The configuration of the features recorded in 1992 match structure locations shown on the 1941 aerial photograph. The domestic debris at HT-92-023 includes ceramic fragments, zinc canning jar lids, glass fragments (clear, pink, and brown), and stove and oven pieces. A trademark on a plate fragment, "Homer Laughlin, green on white, Empress $320 \mathrm{~N}$ " provides a manufacturing date of March 1920 (Lehner 1988, p. 246). A second manufacturing date was noted on a galvanized pipe impressed with "Nov. 10th, 1926." A third date, taken from a 1920s-era coupe (automobile), fits temporally with the first two dates and suggests that the inhabitants were present from circa 1920s or 1930's through 1941.

HT-92-024. This historic complex as indicated on the 1941 aerial photograph is probably associated with HT-92-014; both sites were joined by a well-used gravel road still present today. When the area was surveyed in 1992 very little of the five to eight structure complex pictured on the 1941 aerial photograph was apparent to surveyors. It is likely that HT-92-024 represents a fruit processing/storage area because of its location on the 122-m (400-ft) contour above extensive orchards and several roadways that encircle it and join here. Below this contour, surveyors located what appeared to be a cobble foundation, fireplace, and associated dugout cut into the lower extent of the upper terrace. Immediately north of the foundation is a large, rectangular area of severe disturbance. Numerous glass and metal fragments were noted throughout the area of disturbance but none were large enough to determine artifact function or type. 
HT-92-025. This site offers an interesting anomaly that is not readily visible on the 1941 historic aerial photograph. A large collection of fieldstone was found in a shallow depression; some of the stones appeared to be placed in such a way as to form low, linear walls but no consistent pattern or placement could be determined. Other artifacts included a $1.22-\mathrm{m}(4-\mathrm{ft})$ strand of wire, concrete pipe fragments, metal fragments, wire nails, kerosene cans, milk cans, and sanitary cans. The obvious lack of any well-defined roadway and the presence of discarded items normally associated with machinery repairs and other activities represented in the general area surrounding this location indicate that the field stone and debris were likely transported to this location by tractor, or other vehicle, from nearby fields.

HT-92-026. This historic site contains more than 155 historic artifacts; a single cryptocrystalline projectile point was also found here inside the lower half of a brown bottle glass fragment. A dugout feature with large wood posts, rock piles, and associated stove pipe was also recorded at this site. The presence of a ceramic flower pot, window glass, canning jars, dishware fragments, and assorted cans suggests that this location once sported a dwelling. Although such a structure is not visible on the 1941 aerial photographs, two roads trending northerly/southerly traverse the landscape on either side of the site. The site was and continues to be located in a $1 / 4$ section that was not farmed. A myriad of roadways pass through this NW $1 / 4$ of Section 13, connecting farmsteads and providing obvious "shortcuts" to longer routes along established roadways at section lines.

HT-92-027. This site contains a series of five bermed depressions, burlap fragments, meat cans, brown and clear glass fragments, and small oil cans, all of which suggest that this location was associated with military activities. Evidence of this site could not be located on the 1941 aerial photograph.

HT-92-028. Eleven features were recorded at this location in 1992. The 1941 aerial photography depicts a complex of structures and roadways at this same location. Of particular interest is that this complex is surrounded by open fields with the exception of a narrow stand of young orchard trees that trends west from the northwestern comer of the complex. The historic artifacts recorded here include domestic debris and wood fragments.

HT-92-029. This is one of the more significant sites recorded during the 1992 field season. This historic complex is all that remains of what was an extensive complex of structures in 1941. Although bulldozing effectively removed buildings, evidence of their location still remains. The presence of in-line cottonwoods, stepped riverside terraces, a cobble-and-mortar foundation, numerous outbuilding foundations, an irrigation system, and cement boat launch with a wench/track system for pulling loads up the riverbank attest to the efforts devoted to land improvements. The historic artifacts provide an even richer texture to the site; a metal baby carriage or wagon, clear glass canning jars, an interior electric light, 
and large gate door with hinge and wire attached. A buried prehistoric component is also indicated by the presence of lithic debris in roads; this buried component may extend west and include site HT-92-032.

HT-92-030. This small historic dump with a predominantly glass artifact assemblage seems to be unassociated with any nearby structures or farming complexes. The site is, however, located along informal 1941 roadways that connect it with site HT-92-029. Additional research will be required to determine connections, if any, with surrounding farmsteads.

HT-92-031. This is a second small historic dump that contains mostly domestic artifacts and is also apparently removed from structures. HT-92-031 is likely associated with the extensive historic site HT-92-029 because there are many informal roadways (1941) connecting this location to HT-92-029. One piece of pottery found here contained a trademark, "Vernon China, Vernon, California," which was manufactured from 1928 to 1948 (Lehner 1988, pp. 488-489).

HT-92-032. The presence of lithic debitage, fire-cracked rock, and historic debris in a below-grade road surface provides some preliminary evidence that although prehistoric sites are present in the 100-HR-3 Operable Unit, they are not readily apparent for a variety of reasons including rapid deposition rates, i.e., burial or removal of artifacts by amateur collectors, and/or visibility limitations due to vegetation and Hanford construction activities. A total of 26 flakes and artifacts, all crytocrystalline silica, and 9 pieces of fire-cracked rock were recorded at HT-92-032. These items include the midsection of a biface and a cobble core. The road cuts through the northern edge of a small stabilized dune. Stands of rye grass are present on and around the dune.

HT-92-033. Three fire-cracked rocks, one hammerstone, and four cobble cores (10 $20 \mathrm{~cm}$ ) were recorded within an area of $5 \mathrm{~m} \mathrm{x} 75 \mathrm{~m}$ along the cobblestone beach directly east of a narrow, deep arroyo. This location is directly north of HT-92-032, which is a prehistoric lithic scatter with associated fire-cracked rock. Although the artifacts are occasionally underwater and are probably moved by water action, their proximity to HT-92-032 and HT92-029 suggests that prehistoric use of this general area was widespread either spatially and/or temporally.

HT-92-034. Two components are present at this site, several linear rock piles along the steep cobble beach north of a widely scattered historic dump. The rock piles appear to have been dumped as opposed to "placed," while the historic dump contains a variety of mostly domestic artifacts. Two trademarks were recorded by surveyors at this site. A "Mayflower" shape trademark noted on two dishware fragments was used by the Edwin M Knowles China Company in approximately 1925 (Lehner 1988, p. 237). A second trademark "Trellis L" was 
manufactured by the Homer Laughlin China Company, but manufacturing dates for this pottery type are unknown (Lehner 1988, p. 247). A third item provides an excellent date for occupation and/or dumping activities, a 1934 automobile license plate from South Dakota.

HT-92-035. One depression and three dumps are located near a crossroads directly west of HT-92-029. Perhaps the most interesting item found here was a gramophone funnel.

HT-92-036. Seventeen depressions ranging in size from 3 to $4 \mathrm{~m}$ were found along the river terrace edge for a distance of approximately $180 \mathrm{~m}$. At this location the Columbia River flows through a deep, narrow channel. The possibility that these depressions are the remains of pithouses cannot be discounted, but none of the pithouse depressions contained any evidence of hearths or fire-cracked rock, and pithouse depressions are often larger. Therefore, these depressions may indicate a functional use other than habitation, such as placement of fishing platforms or other activities associated with fishing.

HT-92-037, 45BN145. This site consists of a series of shallow depressions located between the Columbia River and a small rise. Between the steep cobble beach and the small rise, there are three circular depressions and one long ovate depression. These depressions were moist when recorded in July 1992 and appear to be flooded occasionally throughout the year. The riparian vegetation is very dense so visibility at the site is minimal. This same location was first recorded by David Rice in 1968 (Rice 1968a). Rice states "This is an ethnographically reported camp site located on the south bank of the Columbia opposite a large island upstream from Locke Island. The site consists of three or four mat lodge depressions on a gravel bar close to water's edge. Much camp rock and many flakes are scattered around the encampment. The site was reportedly last occupied about 1915" (Rice 1968a).

HT-92-038. Most of the historic artifacts included in this dump are domestic, i. e., cans, ceramics, drinking glass and canning jar fragments, and a few personal items such as shoe fragments and a white glass jar with the trademark "PONDS" on two sides. There is no evidence of any structures nearby, so any associations with farmsteads to the east or south must await further analysis.

HT-92-039. Over 160 historic artifacts were recorded in four separate locations at this site. Artifacts were predominantly domestic, including both ceramic and porcelain dishware fragments, cans, graniteware, crockery, coffee cans, amethyst glass fragments, and other items. These dump areas are likely associated with HT-902-019, an extensive foundation complex and artifact scatter, located immediately south of HT-92-039. 
HT-92-040. This large, sprawling site offered surveyors an interesting enigma. Seven distinct historic features, including an irregular grouping of more than $\mathbf{3 0}$ rock piles (cobble), were recorded near the $122-\mathrm{m}(400-\mathrm{ft})$ contour line approximately $800 \mathrm{~m}(0.5 \mathrm{mi})$ south of the Columbia River. An estimated 3000 historic artifacts are present at 6 dump sites widely scattered across the $52,500 \mathrm{~m}^{2}$ site.

Some of the more interesting diagnostic items include a square, paneled medicine bottle, a brown glass bottle embossed with "FEDERAL LAW (illegible word) PROHIBITS SALE OR REUSE OF THIS BOTTLE", amethyst, amber, and clear glass fragments, ceramic fragments with trademarks - "HOME (illegible word) Made in USA" and "Trellis L". These diagnostic artifacts provide some interesting data. According to Rock ${ }^{(2)}$ the statement "Federal law prohibits sale or reuse of this bottle" was embossed on liquor bottles from 1933 to 1965. Glass color also provides some temporal information. Clear glass manufactured from 1880 to 1916 contained manganese, an additive that turns amethyst when exposed to sunlight. ${ }^{(a)}$ When manganese supplies were interrupted by World War I, selenium was added instead. Selenium causes clear glass to turn amber when exposed to sunlight. The "Trellis L" trademark found on ceramic fragments at this site was also found on a ceramic fragment approximately $800 \mathrm{~m}(0.5 \mathrm{mi})$ north at HT-92-034, suggesting that an irregular pattern of dumping household trash was common in the area. More importantly, the connection between widely separated ceramic artifacts highlights the possibility that "Trellis $\mathrm{L}$ " ceramics may be present at any of the nearby sites retaining foundations.

HT-92-041. This site provides an interesting aspect of the military presence on the Hanford Site. Although military activities are not normally considered (yet) to be historic, the significance of military activities on the Hanford Site cannot be denied. Of particular interest at this site are four rock alignments that spell "Gun 1", "Gun 2", "Gun 3", and "Gun 4", canister lids impressed with the words "4.7 inch gun T2 Container 4.7 inch M79," and a large cobble with several names painted on it.

HT-92-042. This is a small $28 \mathrm{~m}^{2}$ dump containing a variety of primarily domestic items. Several items provide diagnostic dates including amethyst glass fragments known to date to no later that 1917 and amber glass fragments that postdate 1917. There is no apparent association between this site and any of the habitation sites located within a $402 \mathrm{~m}(0.25 \mathrm{mi})$ radius.

HT-92-043. This site is located on a Columbia river cobble beach, extends up the gently sloping bank, and includes the first low terrace. There is very limited visibility in the terrace area due to dense grass and willow cover. Four depressions on the cobble beach are shallow,

(a) Rock, J. 1990. "Basic Bottle Identification." Typescript on file at the Hanford Cultural Resources Laboratory, Pacific Northwest Laboratory, Richland, Washington. 
dish-shaped, and fill with water during river fluctuations. Two depressions located on a slightly higher rise above the cobble beach measure approximately 10 to $12 \mathrm{~m}$ in diameter and are approximately $1 \mathrm{~m}$ deep. These depressions may be an extension of site 45BN146 located approximately $50 \mathrm{~m}$ to the west. Additional depressions not recorded in 1992 are likely to be present where dense vegetation precludes visibility.

HT-92-044. This site includes five historic trash scatters that are located along the 122-m (400-ft) contour line and contains over 520 artifacts. The debris is predominantly domestic and includes amethyst glass fragments, cans manufactured from 1920 to 1931 and from 1917 to 1929 , and a variety of ceramic fragments.

HT-92-045. This is one of the unique military sites recorded during the 1992 field season. The site is south of HT-92-041 where a large cobble, painted with names, was located. HT-92-045 retains a baseball diamond complete with a wire and milled-lumber backstop, bases, pitcher's mound, and several foundation/depression features that suggest the past presence of structures, both military and farmstead.

HT-92-046. This site contains several features including a cement foundation and over 105 historic artifacts, most associated with construction, i.e., nails, concrete fragments, brick, and window glass fragments. A few items suggested a limited domestic emphasis: glass canning jars, food cans, brown bottle fragments (probably beer), and one clear glass liquor bottle fragment. This site is visible on the 1941 aerial photographs, which show five or six buildings.

HT-92-047. The most visible feature at this site is a pile of large cement pieces that appears to have been a large cement building or building foundation. Also present are strips of asphalt, such as those found in parking lots; covered manholes; what appears to be a buried septic system; two large open trenches; and remnants of a small orchard. There is very little domestic debris present. The site is not shown on the 1941 aerial photographs.

HT-92-048. Four domestic dumps, all connected by widely scattered historic debris, are located at $119.7 \mathrm{~m}$, just under the $122-\mathrm{m}(400-\mathrm{ft})$ contour line recorded as the high-water mark for a 1948 flood. The location of the debris at the foot of the 122-m (400-ft) terrace suggests that many of the artifacts were dropped and/or moved to this location during the flood; however, some dumping associated with HT-92-016 and HT-92-017, two recorded habitation complexes immediately adjacent and south, is also likely. Historic aerial photography (1941) indicates that several roadways connected the dump sites at HT-92-048 with HT-92-016 and HT-92-017. These connecting roadways, although faint, were still present when these sites were recorded in 1992. 
HT-92-049. This site is made up of four features consisting of a foundation, a groundwater well, a coal pile, and what appears to be a small collapsed structure. Both domestic and army debris are present.

\section{Area Test Excavations at Sites 45BN432, 45BN433, and 45BN423}

Between July 20 and September 15, 1992, HCRL undertook test excavations at three archaeological sites as part of 100 Area Operable Unit CERCLA characterization studies.

Sites 45BN432 and 45BN433. These archaeological sites are situated on a Holocene terrace overlooking the Columbia River, directly east of the $100 \mathrm{~F}$ Area. The two sites were treated as a single study unit because field reconnaissance indicated the boundary separating the sites was artificially created by an outfall line leading from the reactor complex to the river. The total area for both sites measured $250 \mathrm{~m}$ east/west by $40 \mathrm{~m}$ north/south.

Preliminary analysis indicates most of the cultural material is located within the overlying eolian sediments. The overall size and individual weights of artifacts decreased from west to east. Cultural material consisted primarily of small lithic debitage, principally bifacial thinning flakes and resharpening flakes, small fragments of mammal bone, and pieces of extremely fragmented freshwater mussel shell (Margratifera falcata).

The evidence collected from auger and test units suggests that the majority of the sites' areal expanse was formed through redeposition of small cultural materials by wind in an active dune environment. Analysis of the strike and dip of bedding planes exposed in unit profiles indicates that the source for most of the material would lie to the southwest of current site boundaries, an area heavily impacted by reactor operations.

Site 45BN423. This archaeological site is located on the remains of a Holocene terrace between the Columbia River and the $100 \mathrm{~K}$ Area. The majority of this terrace, with the exception of the near-river edge, was removed to construct emergency overflow holding ponds for the $100 \mathrm{~K}$ Basins. The remaining terrace and associated archaeological site measure approximately $200 \mathrm{~m}$ east/west by $30 \mathrm{~m}$ north/south. Little cultural material is visible on the ground surface across the terrace top; however, abundant material is apparent in shell lenses exposed in a borrow pit on the terrace and in profiles made by outfall trenches.

At least six distinct cultural strata were located during excavations. Strata were separated by culturally sterile levels, thick bands of calcium carbonate, or culturally deposited beds of freshwater mussel (Margratifera falcata). Radiocarbon samples were collected for these strata, but results are not yet available. Relative dates are available for the two uppermost strata, 
based on the recovery of a Quilomene Bar-style projectile point and a Frenchman Springs-style projectile point, indicating ages of 1500 to 2500 years B.P. and 2500 to 4500 years B.P., respectively.

Aside from the stylistic differences of the two projectile points, the remainder of the cultural material is fairly uniform, consisting of a variety of hammer stones, unshaped pestles, retouched and utilized flakes, incised stones, freshwater mussel (Margratifera falcata), remains of rabbits and ungulates, and fish vertebrae. Analysis of stone waste flakes indicates that stone tool production was limited to final finishing and maintenance of tools. Locally available cryptocrystalline silicates were the preferred materials.

In general, this site appears to have functioned as a continually reoccupied resource procurement site, spanning as much as 6000 years. The excellent integrity of the deposits, coupled with the preservation of organic remains and distinct stratification, makes the information potential of this site exceptional. Further work is recommended. Fieldwork should be designed to refine the chronology of occupation, range of resources exploited, climatic reconstruction, and distribution of individual activity areas. 


\section{Conclusions}

During spring and summer 1992, the HCRL conducted a literature review, archaeological survey and excavation in the 100 Area Operable Unit on the Hanford Site. The areas in question cover a total of $1058 \mathrm{ha}$, of which 518 ha were surveyed during the 1992 field season. Approximately 540 ha of the total acreage in the 100-HR-3 Operable Unit remain unsurveyed. Thirty-nine sites were recorded during the survey, and three sites were excavated to determine their eligibility for inclusion on the National Register of Historic Places. Of the sites recorded during the 1992 field season, 27 are attributable to Euro-American farmsteading activity during the early twentieth century, one is an isolated find, three are associated with military activities, and three contain both historic and prehistoric components. Five sites are from Native American occupation, with a probable temporal span ranging from as early as 7000 B.P. to the middle of the twentieth century A.D. The results of test excavations at sites 45BN432, 45BN433, and 45BN423 suggest that only site 45BN423 is eligible for inclusion on the National Register of Historic Places. This site retains excellent stratigraphic integrity, with at least six distinct cultural strata. Although radiocarbon dates have not yet been received, two projectile point styles suggest a temporal range of 1500 to 2500 years B.P. and 2500 to 4500 years B.P. ${ }^{(a)}$

Seven sites are adjacent to the Columbia River shoreline or on high terraces immediately above the shoreline. Eight of the sites are located along the $122-\mathrm{m}(400-\mathrm{ft})$ contour line. Sites on the higher terrace, including Euro-American and Native American sites, are at higher risk of sustaining impact during CERCLA characterization studies (Table 2). Also at high risk are seven sites recorded in 1991 that lie adjacent to or are intersected by radiation zones along the river floodplain, including sites 45BN150, 45BN151, 45BN423, 45BN424, 45BN432, 45BN433, and 45BN439. Three additional sites, 45BN431, 45BN435, and 45BN446, are in proximity to frontage roads or launch facilities and may receive direct and/or indirect impacts from remediation activities that will follow characterization studies (Table 2).

An evaluation of the significance of all sites discovered in FY 1991 and FY 1992 will be conducted in FY 1993 and FY 1994. Requests for Determination of Eligibility, Findings of Effect and Adverse Effect, and plans for mitigation of adverse effects to significant historic properties will be prepared and submitted to the Washington State Historic Preservation Officer, Advisory Council for Historic Preservation, and interested parties (including Indian Tribes) on an as-needed basis. In the interim, all excavation work and road building

(a) Gard, H. A. 1993. "Preliminary Analysis of Site 45BN423." Typescript on file, Hanford Cultural Resources Laboratory, Pacific Northwest Laboratory, Richland, Washington. 
Table 2. FY 1992 Sites at Risk from Characterization Work Identified Risk

\begin{tabular}{|c|c|c|c|c|c|c|}
\hline $\begin{array}{c}\text { Site } \\
\text { Number }\end{array}$ & $\begin{array}{c}\text { Washington } \\
\text { Number }\end{array}$ & $\begin{array}{c}\text { Land } \\
\text { Area }\left(\mathrm{m}^{2}\right)\end{array}$ & 卷 & $\frac{\frac{0}{0}}{20}$ & 离 & 可 \\
\hline HII-92-006 & & 1 & $\checkmark$ & & & \\
\hline HT-92-011 & & 200 & $\checkmark$ & $\checkmark$ & 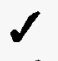 & \\
\hline HT-92-012 & & 100 & $\checkmark$ & $\checkmark$ & $\checkmark$ & \\
\hline HT-92-013 & & 18,750 & $\checkmark$ & $\checkmark$ & $\checkmark$ & \\
\hline HT-92-014 & & 2,688 & $\checkmark$ & $\checkmark$ & $\checkmark$ & \\
\hline HT-92-015 & & 1,440 & $\checkmark$ & $\checkmark$ & $\checkmark$ & \\
\hline HT-92-016 & & 42,000 & $\checkmark$ & $\checkmark$ & $\checkmark$ & \\
\hline HT-92-017 & & 14,400 & $\checkmark$ & $\checkmark$ & $\checkmark$ & \\
\hline HT-92-018 & & 7,208 & $\checkmark$ & $\checkmark$ & $\checkmark$ & \\
\hline HT-92-019 & & 9,350 & $\checkmark$ & $\checkmark$ & $\checkmark$ & \\
\hline HT-92-020 & & 4,528 & $\checkmark$ & $\checkmark$ & $\checkmark$ & \\
\hline HT-92-021 & & 200 & $\checkmark$ & $\checkmark$ & $\checkmark$ & \\
\hline HT-92-023 & & 26,250 & $\checkmark$ & $\checkmark$ & $\checkmark$ & \\
\hline HT-92-024 & & 15,750 & $\checkmark$ & $\checkmark$ & $\checkmark$ & \\
\hline HT-92-025 & & 625 & $\checkmark$ & $\checkmark$ & $\checkmark$ & \\
\hline HT-92-026 & & 18 & $\checkmark$ & $\checkmark$ & $\checkmark$ & \\
\hline HT-92-027 & & 12,000 & $\checkmark$ & $\checkmark$ & $\checkmark$ & \\
\hline HT-92-028 & & 40,000 & $\checkmark$ & $\checkmark$ & $\checkmark$ & \\
\hline HT-92-029 & & 1,200 & $\checkmark$ & $\checkmark$ & $\checkmark$ & \\
\hline HT-92-030 & & 500 & $\checkmark$ & $\checkmark$ & $\checkmark$ & \\
\hline HT-92-031 & & 1,625 & $\checkmark$ & $\checkmark$ & $\checkmark$ & \\
\hline HT-92-032 & & 2,100 & $\checkmark$ & $\checkmark$ & $\checkmark$ & \\
\hline HT-92-033 & & 375 & $\checkmark$ & $\checkmark$ & $\checkmark$ & \\
\hline HT-92-034 & & 2,800 & $\checkmark$ & $\checkmark$ & $\checkmark$ & \\
\hline HT-92-035 & & 7,800 & $\checkmark$ & $\checkmark$ & $\checkmark$ & \\
\hline HT-92-036 & & 8,100 & $\checkmark$ & $\checkmark$ & $\checkmark$ & \\
\hline HT-92-037 & 45BN145 & 22,500 & $\checkmark$ & & & \\
\hline HT-92-038 & & 200 & $\checkmark$ & $\checkmark$ & & \\
\hline HT-92-039 & & 1,100 & $\checkmark$ & $\checkmark$ & & \\
\hline HT-92-040 & & 52,500 & $\checkmark$ & $\checkmark$ & & \\
\hline HT-92-042 & & 28 & $\checkmark$ & $\checkmark$ & & \\
\hline HT-92-043 & & 3,200 & $\checkmark$ & & & \\
\hline HT-92-044 & & 30,800 & $\checkmark$ & $\checkmark$ & & \\
\hline
\end{tabular}


Table 2. (Contd)

\begin{tabular}{|c|c|c|c|c|c|c|c|}
\hline \multirow[b]{2}{*}{$\begin{array}{c}\text { Site } \\
\text { Number }\end{array}$} & \multirow[b]{2}{*}{$\begin{array}{c}\text { Washington } \\
\text { Number }\end{array}$} & \multirow[b]{2}{*}{$\begin{array}{c}\text { Land } \\
\text { Area }\left(\mathrm{m}^{2}\right)\end{array}$} & \multicolumn{5}{|c|}{ Identified Risk } \\
\hline & & & 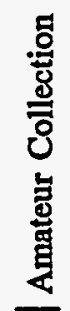 & 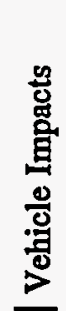 & 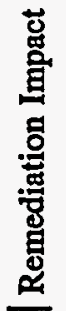 & 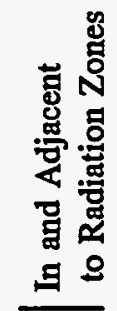 & 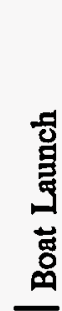 \\
\hline HT-92-045 & & 6,800 & & 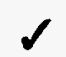 & $\checkmark$ & & \\
\hline HT-92-046 & & 2,597 & $\checkmark$ & $\checkmark$ & $\checkmark$ & & \\
\hline HT-92-047 & & 22,500 & $\checkmark$ & $\checkmark$ & $\checkmark$ & & \\
\hline HT-92-048 & & 175,000 & $\checkmark$ & $\checkmark$ & & & \\
\hline HT-92-049 & & 9,375 & $\checkmark$ & $\checkmark$ & $\checkmark$ & & \\
\hline & 45BN150 & Unknown & & & & 1 & \\
\hline & 45BN151 & Unknown & & & & $s$ & \\
\hline & 45BN423 & Unknown & & & & $\checkmark$ & \\
\hline & $45 \mathrm{BN} 424$ & 46,875 & & & & $\checkmark$ & \\
\hline & $45 \mathrm{BN} 432$ & 5,520 & & & & $s$ & \\
\hline & $45 \mathrm{BN} 433$ & Unknown & & & . & 1 & \\
\hline & 45BN439 & 30,530 & & & & 1 & \\
\hline & 45BN431 & 4,250 & & $\checkmark$ & . & & 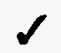 \\
\hline & 45BN435 & 950 & & $\checkmark$ & 。 & & 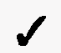 \\
\hline & 45BN446 & 15,000 & & $\checkmark$ & . & & $\checkmark$ \\
\hline
\end{tabular}

associated with CERCLA characterization of the 100 Areas will be reviewed by the HCRL, and plans will be adjusted by DOE to avoid impacts to cultural resources whenever possible. Cases where this is not possible are not foreseen at this writing. 


\section{References}

Bacon, V.R. 1983. "Eruptive History of Mount Mazama and Crater Lake Caldera, Cascade Range, U.S.A." Joumal of Volcanology and Geothermal Research, 18:57-117.

Chatters, J. C. 1989. Hanford Cultural Resources Management Plan. PNL-6942, Pacific Northwest Laboratory, Richland, Washington.

Chatters, J. C., N. A. Cadoret, and P. E. Minthorn. 1990. Hanford Cultural Resources Laboratory Annual Report for Fiscal Year 1989. PNL-7362, Pacific Northwest Laboratory, Richland, Washington.

Chatters, J. C., H. A. Gard, and P. E. Minthorn. 1991. Hanford Cultural Resources Laboratory Annual Report for Fiscal Year 1990. PNL-7853, Pacific Northwest Laboratory, Richland, Washington.

Chatters, J. C., H. A. Gard, and P. E. Minthorn. 1992. Fiscal Year 1991 Report on Archaeological Surveys of the 100 Areas, Hanford Site, Washington. PNL-8143, Pacific Northwest Laboratory, Richland, Washington.

Dawson, M. 1993. Hanford Cultural Resources Laboratory Procedures Handbook. PNL-MA-567, Pacific Northwest Laboratory, Richland, Washington.

Lehner, L. 1988. Lehner's Encyclopedia of U.S. Marks on Pottery, Porcelain and Clay. Collector Books, Paducah, Kentucky.

Relander, C. 1956. Drummers and Dreamers. Caxton Printers, Caldwell, Idaho.

Rice, D. G. 1968a. Archaeological Reconnaissance Hanford Atomic Works. National Park Service, U.S. Atomic Energy Commission. Washington State University, Pullman, Washington.

Rice, D. G. 1968b. Archaeological Reconnaissance: Ben Franklin Reservoir Area, 1968. Washington State University, Laboratory of Anthropology, Pullman, Washington.

Rice, D. G. 1983. Cultural Resources at Hanford. Washington Public Power Supply System and U.S. Department of Energy, Richland, Washington. 


\section{Distribution}

No. of

Copies

\section{OFFSITE}

2 DOE Office of Scientific and

Technical Information

M. Thompson

State Historic Preservation

Officer

Office of Archaeology \& Historic

Preservation

111 West 21st Ave., KL-11

Olympia, WA 98504-5411

D. Hogan

U.S. Army Corps of Engineers

Box C-3755

Seattle, WA 98124-2255

K. Sycamore

National Park Service,

Pacific Northwest Region

83 King St., Suite 212

Seattle, WA 98104

J. Leier

U.S. Army Corps of Engineers

Walla Walla District

Building 602, City-County Airport

Walla Walla, WA 99362-9265

2 Colville Confederated Tribes

Attn: Tribal Council

A. Fredin

P.O. Box 150

Nespelem, WA 99155
No. of

Copies

2 Nez Perce Tribe

Attn: Tribal Council

A. Slickpoo

P.O. Box 305

Lapwai, ID 83540

2 The Confederated Tribes of the

Umatilla Indian Reservation

Attn: Tribal Council

J. Van Pelt

P.O. Box 638

Pendleton, OR 97810

2 The Wanapum Indian Tribe

Attn: Tribal Council

R. Buck, Jr.

P.O. Box 275

Beverly, WA 99321

2 The Yakima Indian Nation

Attn: Tribal Council

B. Yallup

P.O. Box 151

Toppenish, WA 98948

3 Washington Department of Ecology 99 S. Sound Center

Lacey, WA 98504

Attn: C. Cline

S. F. Cross

L. Goldstein

2 Washington Department of Ecology 7601 W. Clearwater, Suite 102

Kennewick, WA 99336

Attn: P. D. Teel 
No. of

Copies

ON SITE

27 DOE Richland Operations Office

K. V. Clarke

A5-15

P. F. Dunigan

A5-15

B. L. Foley

A5-19

E. D. Goller (10)

A5-19

J. D. Goodenough

A5-19

N. M. Highland

A7-27

M. B. Hitt

A7-27

R. D. Izatt

A5-15

C. R. Pasternak (5)

A7-27

E. E. Pride

A4-52

J. R. Shadel

A5-90

K. M. Thompson

A5-15

DOE Legal Library

A4-78

A1-65

4 U.S. Environmental Protection Agency

P. R. Beaver

B5-01

D. A. Faulk

L. E. Gadbois

B5-01

B5-01

P. S. Innis

B5-01

33 Westinghouse Hanford Company

M. R. Adams

H6-01

J. M. Ayres

H6-02

R. L. Biggerstaff

J. R. Culmer

H6-02

$\mathrm{XO}-21$

R. H. Englemann

T. W. Ferns

H6-26

H6-26

G. E. Fitzgibbon

H6-07

K. A. Gano

$\mathrm{XO}-21$

M. W. Gerber

G. C. Henckel

H6-04
No. of

Copies

R. P. Henckel

H6-02

N. A. Homan

H6-02

W. L. Johnson

H6-04

A. D. Krug

H6-02

M. J. Lauterbach H6-01

R. M. Mitchell

H6-04

N. M. Naiknimbalkar H6-02

K. L. Peterson H4-14

J. W. Roberts H6-02

R. V. Roeck

H6-01

H6-02

H6-02

$\mathrm{XO}-41$

H6-26

H6-02

L8-04

$\mathrm{H} 4-22$

33 Pacific Northwest Laboratory

R. H. Gray

K1-33

R. E. Jaquish

K1-30

G. V. Last

K6-96

J. G. Longenecker (20)

K6-06

L. E. Rogers

P7-54

R. E. Schrempf

M. K. Wright

K6-86

Publishing Coordination

Technical Report Files (5)

Routing

R. M. Ecker

SE-UI

M. J. Graham

K6-80

P. M. Irving

K6-98

C. S. Sloane

K6-04

P. C. Hays (last)

K6-86 